\title{
Extract of ceplukan (Physalis angulata L.) inhibited proliferation and induced apoptosis in myeloma cell line
}

\author{
${ }^{1}$ Maryati, ${ }^{2}$ Sutrisna, E., ${ }^{1}$ Saifudin, A., ${ }^{3}$ Kusumaningrum, I.D. and ${ }^{4}$ Abu Bakar, M.F. \\ ${ }^{1}$ Faculty of Pharmacy, Universitas Muhammadiyah Surakarta, Jalan A. Yani, Tromol Pos 1, Pabelan \\ Kartasura, Surakarta, Central Java, Indonesia. \\ ${ }^{2}$ Faculty of Medicine, Universitas Muhammadiyah Surakarta, Jalan A. Yani, Tromol Pos 1, Pabelan \\ Kartasura, Surakarta, Central Java, Indonesia \\ ${ }^{3}$ STIKES Kendal, Central Java, Indonesia \\ ${ }^{4}$ Faculty of Applied Sciences and Technology, Universiti Tun Hussein Onn Malaysia (UTHM), Hub \\ Pendidikan Tinggi Pagoh, KM1, Jalan Panchor, 84600, Muar, Johor, Malaysia.
}

\section{Article history:}

Received: 20 April 2019

Received in revised form: 30 May 2019

Accepted: 1 June 2019

Available Online: 20 June 2019

\section{Keywords:}

Physallis angulata L.,

Myeloma cell,

MTT,

Cytotoxic,

Apoptosis

\section{DOI:}

https://doi.org/10.26656/fr.2017.3(6).169

\begin{abstract}
Cancer is one of the main causes of death globally. Thus, research to develop a new cancer drug is still ongoing. Physallis angulata L. (ceplukan) is one of the Indonesian plants that has been shown to display anti-cancer activity. This research aimed to examine the cytotoxic effect of ethanol extract of $P$. angulata $\mathrm{L}$., the effect on cell proliferation and the apoptosis-inducing ability against myeloma cells. $P$. angulata L. plant was extracted using 96\% ethanol. The observations of the cytotoxic effect of extract and the proliferation of myeloma cells were done by MTT assay. The effect of the extract on apoptosis was determined by double staining method using ethidium bromide-acridine orange. Markers for apoptosis were measured by immunocytochemistry test. The results showed that the extract of $P$. angulata exhibited cytotoxic effects on myeloma cells with an $\mathrm{IC}_{50}$ value of $70.92 \mu \mathrm{g} / \mathrm{ml}$. The extract inhibited the proliferation of myeloma cells and induced apoptosis in myeloma cancer cells by upregulating the expression of p53 and Bax. This result suggested that ethanolic extract of $P$. angulata L. had the potential to be developed as blood cancer drug. Further study on the isolation of the bioactive compound and in vivo mechanism is in progress.
\end{abstract}

\section{Introduction}

Cancer is a disease that causes death worldwide. At present, the treatments of cancer such as surgery, radiation, and chemotherapy have not produced encouraging results (Davis et al., 2003). Thus, research to find more effective cancer drug with minimal side effects are being conducted. Natural products have an essential role in drug discovery and development (Zhang et al., 2017). Indonesia is a country rich in plant-based natural medicine that has been used for generations by the community to treat many diseases including cancer. Physallis angulata L. (ceplukan) is a member of the Solanaceae family which is spread out in tropical countries, including Indonesia. This plant has the potential to be developed as anti-cancer medicine (Sun et al., 2017). Various studies showed that this plant has antitumor, cytotoxic effect, inhibition of the ubiquitin pathway-proteasome (He et al., 2013; Xia et al., 2016; Yang et al., 2018), immunomodulators (Sun et al., 2011), antibacterial (Yang et al., 2016), and anti- inflammatory (Qiu et al., 2008; Sun et al., 2016). The chemical content of these plants that are responsible for these activities includes steroids, flavonoid glycosides, and alkaloids (Lee et al., 2008; Sun et al., 2017).

Previous studies have shown that $P$. angulata extract exhibited immunomodulatory activities (Sun et al., 2011). The ethanol extract of $P$. angulata also induced cytotoxic activity against several cell lines such as HA22T (hepatoma), KB (nasopharynx), Colo 205 and Calu (human lung epithelial cancer) (Chiang et al., 1992). Petroleum ether fraction of $P$. angulata plant can inhibit proliferation and induce apoptosis in HeLa cells (Maryati and Sutrisna, 2011). Ethanol extract of $P$. angulata is potential as an immunomodulatory agent because it can induce the differentiation of bone marrow cells (BMC) into macrophages (da Silva et al., 2014). Other studies also showed that flavonoid glycosides from $P$. angulata exhibited cytotoxic effects against cancer cells (Ismail and Alam, 2001). Other compounds in $P$. angulata that have anticancer potentials are physalin and 
withanolide (Zhang et al., 2017). Sun et al., (2017) isolated five new physalin compounds from the stems and leaves of $P$. angulata and all the five compounds showed antiproliferative activity against human cancer cells (C4-2B, 22Rv1, 786-O, A-498, ACHN, and A375S2). The latest study using a reactivity-based screening (RBS) approach managed to get five new withanolide compounds with cytotoxic activity (Zhang et al., 2017).

At present, the chemotherapy drugs such as etoposide (Karpinich et al., 2002), vincristine (Groninger et al., 2002), 5-fluorouracil (Liu et al., 2008; Mhaidat et al., 2014), or doxorubicin (Eom et al., 2005) work by inducing apoptosis in cancer cells. Therefore, agents that can induce apoptosis or affect cell cycles attracts many researchers. Currently, there is no study report on the cytotoxic effect of this plant on myeloma cells. The aim of this study is to examine the anti-cancer potential of $P$. angulata plant against myeloma cell line.

\section{Materials and methods}

\subsection{Plant Sample}

$P$. angulata L. plant was collected from Gantiwarno, Klaten, Central Java, Indonesia and was identified by botanist Deny Wahyu, S.Si in the Laboratory of Morphology and Plant Physiology, Department of Biology, Faculty of Education and Teaching, University of Muhammadiyah Surakarta, Central Java, Indonesia with the voucher specimen number 122/A.E.1/LAB. $\mathrm{BIO} / \mathrm{III} / 2010$.

\subsection{Extraction}

The whole plant of $P$. angulata $\mathrm{L}$. was dried using the oven at $50^{\circ} \mathrm{C}$ for 3 days. The dried plant was blended into fine powder followed by extraction with $96 \%$ ethanol. The liquid extract was dried by a rotary evaporator. The thick extract obtained was then used for cytotoxic tests, inhibition of cell proliferation, and apoptosis observation.

\subsection{Cytotoxic test}

Myeloma cells were obtained from Parasitology Laboratory, Faculty of Medicine, Universitas Gadjah Mada, Indonesia. The $2.0 \times 10^{4}$ cells/well were seeded into 96 -well plate and incubated at $37^{\circ} \mathrm{C}$, incubator $(5 \%$ $\mathrm{CO}_{2}$ ) for $24 \mathrm{hrs}$. Cells were treated with various concentration of $P$. angulata $\mathrm{L}$. extract $(31.25 ; 62.5 ; 125$; $250 ; 500 \mu \mathrm{g} / \mathrm{mL}$ ). The treated cells were incubated in an incubator $\left(5 \% \mathrm{CO}_{2}\right)$ for $24 \mathrm{hrs}$ at $37^{\circ} \mathrm{C}$. Cells were washed with Phosphate Buffer Saline (PBS), then added with $0.5 \mathrm{mg} / \mathrm{mL}$ MTT (3-(4,5-dimethylthiazol-2-il)-2,5diphenyltetrazolium bromide), incubated for $4 \mathrm{hrs}$ at $37^{\circ} \mathrm{C}$. Cells were added with regent stopper (SDS reagent
$(10 \%)$ in $\mathrm{HCl} 0.01 \mathrm{M})$, incubated overnight at room temperature, $28^{\circ} \mathrm{C}$ (Handayani et al., 2017). The absorbance was measured using the ELISA reader at a wavelength of $550 \mathrm{~nm}$. The percentage of viable cells was calculated from absorbance data. Furthermore, to calculate the $\mathrm{IC}_{50}$, a linear regression equation between the concentration of extract and percent of viable cells was formulated.

\subsection{Observation of proliferation inhibition}

Observation of myeloma cell proliferation inhibition was carried out by using the MTT method, concentration samples were used below $\mathrm{IC}_{50}$ values. Observations were conducted at 24, 48, and 72 hrs (Cancer Chemoprevention Research Center, 2009).

\subsection{Apoptosis Observation}

Cells with a density of $1.5 \times 10^{4}$ cells/well were seeded on coverslips in a 24 -well plate and incubated in $37^{\circ} \mathrm{C}$ incubator $\left(5 \% \mathrm{CO}_{2}\right)$ until confluent. Then, cells were incubated with extract for $24 \mathrm{hrs}$. Next, the medium was taken, and the cells were washed using PBS. The coverslip containing cell was placed into the object glass followed by double staining using $10 \mathrm{~mL} 1 \mathrm{X}$ working solution acridine orange-ethidium bromide (Sigma Aldrich). It was left for 5 mins before immediately observed under a fluorescent microscope (Zeiss MC 80). Green fluorescent indicated the viable cells and orange fluorescence marked the apoptosis cells.

\subsection{Immunocytochemistry assay}

Cells with a density of $1.5 \times 10^{4}$ cells/well were seeded on coverslips in a $24-w e l l$ plate, incubated $37^{\circ} \mathrm{C}$ incubator $\left(5 \% \mathrm{CO}_{2}\right)$ until confluent. Then, cells were incubated with $70 \mathrm{mg} / \mathrm{mL}$ extract of $P$. angulate plant for $24 \mathrm{hrs}$. The medium was removed and washed with PBS. Cells were fixed with acetone for 10 mins and washed with PBS. Cells were added by normal mouse serum (1:50) for 15 mins, removed (without washing), incubated with monoclonal antibody anti-p53 (Dako) and anti-Bax (Dako) (1:50 dilution) for 60 mins at $28^{\circ} \mathrm{C}$, then a washed in PBS 3 times. The preparations were incubated in biotin for 10 mins and washed with PBS twice for 5 mins, followed by incubation in streptavidinperoxidase for 10 mins and washed with PBS (2 times for 5 mins), incubated in DAB for 3-8 mins and washed with distilled water. Cells were stained with hematoxylin for 3-4 mins and washed with distilled water. Coverslips were moved into object-glass, fixed with ethanol and xylol. Protein expression was observed using a light microscope (Nikon YS 100). Compare with the cells without certain protein, cells that expressed certain proteins were brown/dark in color. 


\section{Results and discussion}

\subsection{Cytotoxic test and observation of myeloma cell inhibition}

Cytotoxic tests were done using the MTT method [3(4,5-dimethylthiazol-2-il)-2,5-diphenyltetrazolium bromide]. Compared to dead cell, viable cells can cleave MTT to insoluble purple formazan (Doyle and Griffiths, 2000). Formazan was then dissolved using $10 \%$ SDS in $0.1 \mathrm{~N} \mathrm{HCl}$ and the absorbance was measured with ELISA Reader. The absorbance of solubilized formazan was proportional to the number of viable cells (Cancer Chemoprevention Research Center, 2009). This cytotoxic test illustrated the ability of extracts to inhibit cell growth. Increasing the concentration of extract resulted in a decrease in the percent of viable cells (Figure 1). Based on calculations using linear regression analysis, $P$. angulata extract had cytotoxic activity in myeloma cells with $\mathrm{IC}_{50}$ value of $70.92 \mu \mathrm{g} / \mathrm{mL}$. The morphology of the control cell (no treated extract) appeared to be round and clear. In contrast, the treated cell become shrink and had an irregular shape (Figure 2). Previous research showed that Physalin B, D, F compounds isolated from $P$. angulata plants displayed strong cytotoxic activity on KB cells, A431, HCT-8, PC3 and ZR751 with $\mathrm{IC}_{50}$ less than $4 \mu \mathrm{g} / \mathrm{ml}$ (Kuo et al., 2006). Withangulatin A and withangulatin I which are with the anolide compounds isolated from $P$. angulata plants have been shown to have cytotoxic effects on colorectal carcinoma (COLO 205) and gastric carcinoma (AGS) with $\mathrm{IC}_{50}$ from withangulatin $\mathrm{A}$ are 16.6 and 1.8 $\mu \mathrm{m}$, and $\mathrm{IC}_{50}$ from withangulatin $\mathrm{I}$, are 53.6 and $65.4 \mu \mathrm{m}$, respectively (Lee et al., 2008).

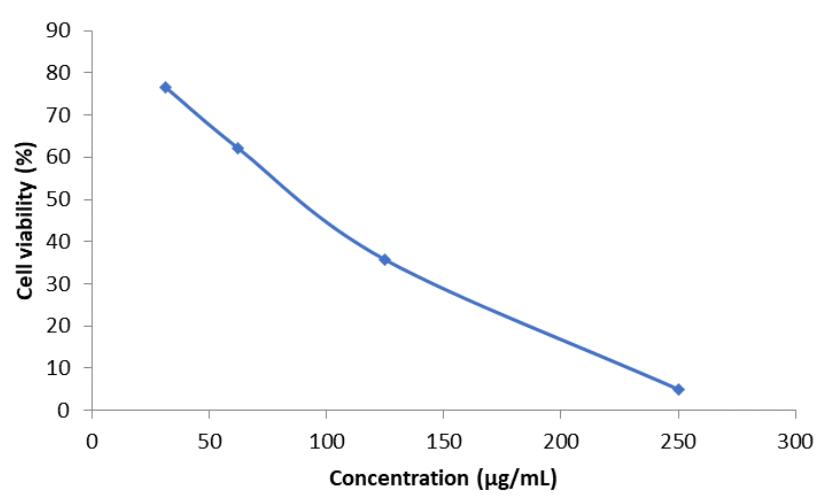

Figure 1. Effect of P. angulata L. extract on myeloma cells.

Furthermore, the inhibition activity of $P$. angulata $\mathrm{L}$. extract against myeloma cells growth was also done using the MTT assay. The absorbance data using the MTT method illustrated the number of viable cells. Compounds that delay the doubling time of cell are thought to inhibit genes or proteins involved in the cell cycle. In this test, two concentrations of extract, below the $\mathrm{IC}_{50}$ value (15 and $30 \mu \mathrm{g} / \mathrm{mL}$ ) were used. It was intended that not too many cells died in the observation for $72 \mathrm{hrs}$ due to the cytotoxic effect of the extract. Observations were carried out at 24, 48, and $72 \mathrm{hrs}$. The results showed that $P$. angulata extract inhibited myeloma cell proliferation. The inhibitory effect of the extract on cell proliferation was directly proportional to its concentration (Table 1). The effect of cell proliferation inhibition from $P$. angulata extract was dose-dependent. These data indicated that treatment with extracts did not stop the cell cycle. This cell proliferation inhibition was related to cell cycle progression inhibition (Yu et al., 2009). A previous study has also shown that the ethanol extract of $P$. angulata plants induces $\mathrm{G}_{2} / \mathrm{M}$ arrest and apoptosis in the MDA-MB 231 human breast cancer and MCF-7 cell line (Hsieh et al., 2006).

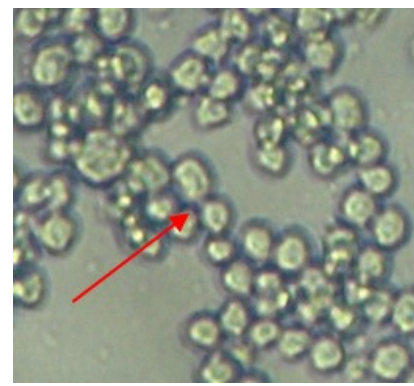

A

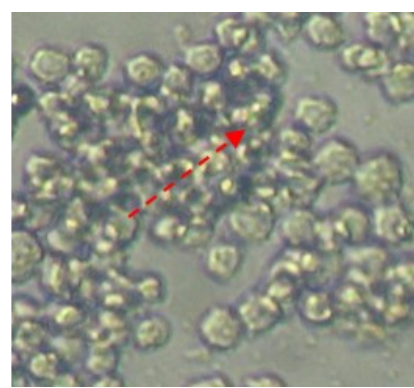

B
Figure 2. Morphology of myeloma cell before (A) and after (B) treatment at $125 \mu \mathrm{g} / \mathrm{mL}$ of P. angulata extract. Myeloma cells before being treated were round and clear while after the ethanol extract treatment (B), the cells were irregular in shape and dark in color.

Table 1. Inhibition effect of $P$. angulata L. ethanol extract in myeloma cell.

\begin{tabular}{cccc}
\hline \multirow{2}{*}{$\begin{array}{c}\text { Time } \\
\text { (hours) }\end{array}$} & \multicolumn{3}{c}{ Inhibition (\%) } \\
\cline { 2 - 4 } & DMSO & Extract $(15 \mu \mathrm{g} / \mathrm{mL})$ & Extract $(30 \mu \mathrm{g} / \mathrm{mL})$ \\
\hline 24 & 5.53 & 17.83 & 25.41 \\
48 & 5.78 & 24.1 & 45.04 \\
72 & 7.36 & 26.16 & 53.90 \\
\hline
\end{tabular}

Other studies have also found many compounds in plants capable of inducing cell cycle arrest and play an important role in prevention and cancer therapy. Soybeans contain genistein, daidzein, and isoflavonoids which play an important role in the prevention of breast cancer (Wang et al., 2002). Another flavonoid, such as quercetin, was able to inhibit cell cycle arrest at G2/M phase and induced apoptosis in human U937 cells (Lee et al., 2006). Apigenin, the main flavonoids in celery exhibited antiproliferation effect on MCF-7 cells (Yin et al., 2001). Curcumin can induce the cell cycle arrest in the $G_{1}$ and $G_{2} / M$ phases (Barti et al., 2003; Van Erk et al., 2003). PGV-0, a derivative compound of curcumin, has also been shown to inhibit T47D breast cancer cell proliferation (Meiyanto et al., 2006). 


\subsection{Apoptosis observation using double staining}

Apoptosis is a cell suicide program to eliminate damaged or abnormal cells (Elmore, 2007). In this study, observations of cell DNA undergoing apoptosis were carried out by double staining using acridine orangeethidium bromide (Kwan et al., 2015). Acridine orange will be absorbed by both viable and dead cells while ethidium bromide is only absorbed by cells that have lost membrane permeability. Acridine orange colors the living cells so that it appears green and ethidium bromide causes orange fluorescence in dead and apoptotic cells (Liu et al., 2015).

Cells undergoing apoptosis have a cell membrane with blebbing characteristics but do not lose their integrity, chromatin and nucleus membrane aggregation, cytoplasm shrinks, core condensation occurs, and cell fragmentation becomes apoptotic bodies (Wyllie et al., 2000; Liu et al., 2015). The results of double staining due to the administration of ethanol extract $50 \mu \mathrm{g} / \mathrm{ml}$ showed the presence of living cells and cells that might experience apoptosis as indicated by orange cells. Meanwhile, the treatment with $75 \mu \mathrm{g} / \mathrm{mL}$ ethanol extract showed a clearer apoptotic phenomenon (cells were orange and apoptotic bodies were formed) (Figure 3). These data indicate that the ethanol extract of $P$. angulata may stimulate apoptosis in myeloma cells.

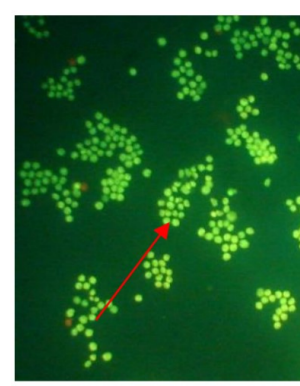

A

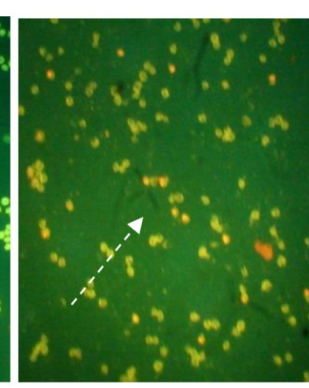

B

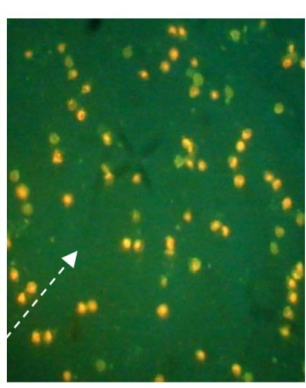

C
Figure 3. Morphology of myeloma cell after double staining with ethidium bromide-acridine orange. Cell control, cells treated with extracts of $50 \mu \mathrm{g} / \mathrm{mL}$, and cells treated with extracts of $75 \mu \mathrm{g} / \mathrm{mL}$ are shown in $\mathrm{A}, \mathrm{B}$, and C, respectively. In cell control, all visible green shows viable cells, whereas there were apoptotic cells (orange) in treated cells.

\section{3 p53 and Bax expressions in myeloma cells}

The p53 protein is a transcription factor of many genes which plays a role in apoptosis, cell cycle, and angiogenesis (Elmore, 2007). The DNA damage causes the $\mathrm{p} 53$ protein to increase the expression of proapoptotic proteins, such as Bax, NOXA, or Puma. Increasing the expression of proapoptosis proteins will stimulate the release of cytochrome $\mathrm{C}$ from mitochondria and stimulate apoptosis (Nakamura, 2004).

In this study, the expression of p53 and Bax proteins in myeloma cells after the treatment with $P$. angulate extract were observed using immunocytochemical staining using horseradish peroxidase enzyme-labeled antibodies. This enzyme reacted with chromogen DAB (diaminobenzidine) into a brown substrate. Cells with positive expressions had a brown/dark color due to the DAB and cells with negative expression had a purple or blue color due to counterstain hematoxylin. Positive protein expressions were compared with negative controls. In the negative control, the painting was done without primary antibodies so that the generated color was only purple or blue due to counterstain hematoxylin.

Results showed an increase in the expression of $\mathrm{p} 53$ and Bax proteins in myeloma cells (Table 2). It was suspected that apoptosis in Myeloma cells was caused by the increase in the expression of p53 and Bax proapoptotic proteins. Previous research reported that physapubenolide, a withanolide isolated from $P$. angulata induced apoptosis in human breast cancer MDA-MB-231 and MCF-7 cells by increasing the expression of $\mathrm{Bax}$ dan $\mathrm{BCl}_{2}$ protein (Ma et al., 2017). This is the first study reported the induction of p53 and Bax proapoptotic proteins by $P$. angulata extract in myeloma cells.

Table 2. Expression of p53 and Bax in myeloma cells in the control and treatment of $75 \mu \mathrm{g} / \mathrm{mL} P$. angulata $\mathrm{L}$. extract

\begin{tabular}{ccc}
\hline Treatment & p53 Expression (\%) & Bax Expression (\%) \\
\hline Control & 18 & 58 \\
$75 \mu \mathrm{g} / \mathrm{ml}$ of extract & 50 & 92 \\
\hline
\end{tabular}

\section{Conclusion}

$P$. angulata has the potential to inhibit the proliferation in myeloma cell with the $\mathrm{IC}_{50}$ value of $70.92 \mu \mathrm{g} / \mathrm{mL}$. Apoptosis in myeloma cell was also induced in $P$. angulata. The results suggested that ethanolic extract of $P$. angulata may be possible to be developed as blood cancer drug.

\section{Conflict of Interest}

The authors declare no conflict of interest.

\section{Acknowledgments}

The authors would like to express our gratitude to the Directorate of Research and Community ServiceMinistry of Research, Technology, and Higher Education of Indonesia for funding this study.

\section{References}

Cancer Chemoprevention Research Center (CCRC). (2009). Protokol. Retrieved from website: http:// ccrc.farmasi.ugm.ac.id/?page_id=240. 
Chiang, H.C., Jaw, S.M., Chen, C.F. and Kan, W.S. (1992). Antitumor agent from Physalis angulata L. Anticancer Research, 12(3), 837.

da Silva, B.J.M., Rodrigues, A.P., Farias, L.H., Hage, A.A.P., Nascimento, J.L.M. and Silva, E. (2014). Physalisangulata induces in vitro differentiation of murine bone marrow cells into macrophages, $B M C$ Cell Biology, 15, 37. https://doi.org/10.1186/14712121-15-37

Davis, J.M., Navolonic, P.M., Weinstein, C.R., Steelman, L.S., Hu, W., Konovlepa, M., Blagosklonny, M.V. and McCubrey, J.A. (203). Raf and BCL-2 induce distinct and common pathway that contribute to breast cancer drug resistance. Clincial Cancer Research, 9(3), 1161-1170.

Doyle, A. and Griffiths, J.B. (2000). Cell and Tissue Culture for Medicinal Research. New York: John Willey and Sons Ltd.

Elmore, S. (2007). Apoptosis: a review of programmed cell death. Toxicology Pathology, 35(4), 495-516. https://doi.org/10.1080/01926230701320337

Eom, Y.W., Kim, W.A., Park, S.S., Goo, M.J., Kwon, H.J., Sohn, S., Kim, W.H., Yoon, G. and Choi, K.S. (2005). Two distinct modes of cell death induced by doxorubicin: apoptosis and cell death through mitotic catastrophe accompanied by senescence-like phenotype. Oncogene, 24, 4765-4777. https:// doi.org/10.1038/sj.onc. 1208627

Groninger, E., Meeuwsen-De Boer, G.J., De Graaf, S.S., Kamps, W.A. and De Bont, E.S. (2002). Vincristine induced apoptosis in acute lymphoblastic leukaemia cells: a mitochondrial controlled pathway regulated by reactive oxygen species? International Journal of Oncology, 21(6), 1339-1445. https://doi.org/10.3892/ ijo.21.6.1339

Handayani, S., Susidarti, R.A., Jenie, R.I. and Meiyanto, E. (2017). Two Active Compounds from Caesalpinia sappan L. In Combination with Cisplatin Synergistically Induce Apoptosis and Cell Cycle Arrest on WiDr Cells. Advanced Pharmaceutical Bulletin, 7(3), 375-380. https:// doi.org/10.15171/apb.2017.045

He, H., Zang, L.H., Feng, Y.S., Chen, L.X., Kang, N., Tashiro, S., Onodera, S., Qiu, F. and Ikejima, T. (2013). Physalin A induces apoptosis via p53-Noxamediated ROS generation, and autophagy plays a protective role against apoptosis through $\mathrm{p} 38-\mathrm{NF}-\mathrm{\kappa B}$ survival pathway in A375-S2 cells. Journal of Ethnopharmacology, 148(2), 544-555. https:// doi.org/10.1016/j.jep.2013.04.051

He, H., Zang, L.H., Feng, Y.S., Wang, J., Liu, W.W., Chen, L.X., Kang, N., Tashiro, S., Onodera, S., Qiu,
F. and Ikejima, T. (2013). Physalin A induces apoptotic cell death and protective autophagy in HT1080 human fibrosarcoma cells. Journal of Natural Products, 76(5), 880-888. https:// doi.org/10.1021/np400017k

Hsieh, W.-T., Huang, K.-Y., Lin, H.-Y. and Chung, J.-G. (2006). Physalis angulata Induced G2/M Phase Arrest in Human Breast Cancer Cells. Food and Chemical Toxicology, 44(7), 975-983. https:// doi.org/10.1016/j.fct.2005.11.013

Ismail, N. and Alam, M. (2001). A Novel Cytotoxic Flavonoid Glycoside from Physalis angulata. Fitoterapia, 72(6), 676-679. https://doi.org/10.1016/ S0367-326X(01)00281-7

Karinpinich, N.O., Tafani, M., Rothman, R.J., Russo, M.A. and Farber, J.L. (2002). The course of etoposide-induced apoptosis from damage to DNA and p53 activation to mitochondrial release of cytochrome C. Journal of Biological Chemistry, 277, 16547-16552. https://doi.org/10.1074/ jbc.M1 10629200

Kuo, P.-C., Kuo, T.-H., Damu, A.G., Su, C.-R., Lee, E.J., Wu, T.-S., Shu, R., Chen, C.M., Bastow, K.F., Chen, T.-H. and Lee, K.-H. (2006). Physanolide A, a Novel Skeleton Steroid Other Cytotoxic principle from Physalis angulate. Organic Letters, 8(14), 2953-2956. https://doi.org/10.1021/ol060801s

Kwan, Y.P., Saito, T., Ibrahim, D., Al-Hassan, F.M.S., Oon, C.E., Chen, Y., Jothy, S.L., Kanwar, J.R. and Sasidharan, S. (2015). Evaluation of the cytotoxicity, cell-cycle arrest, and apoptotic induction by Euphorbia hirta in MCF-7 breast cancer cells. Pharmaceutical Biology, 54(7), 1-14. https:// doi.org/10.3109/13880209.2015.1064451

Lee, S.-W., Pan, M.-H., Chen, C.-M. and Chen, Z.-T. (2008). Withangulatin I, a new Cytotoxic Withanolide from Physallis angulata. Chemical and Pharmaceutical Bulletin, 56(2), 234-236. https:// doi.org/10.1248/cpb.56.234

Liu, H.C., Chen, G.G., Vlantis, A.C., Tong, M.C., Chan, P.K. and Hasselt, C.A.V. (2008). Induction of cell cycle arrest and apoptosis by 5-fluorouracil in laryngeal cancer cells containing HPV16 E6 and E7 oncoproteins. Clinical Biochemistry, 41(14-15), 1117-1125. https://doi.org/10.1016/ j.clinbiochem.2008.06.007

Liu, K., Liu, P.-C., Liu, R. and Wu, X. (2015). Dual AO / EB Staining to Detect Apoptosis in Osteosarcoma Cells Compared with Flow Cytometry. Medical Science, 21, 15-20. https:// doi.org/10.12659/MSMBR.893327

Ma, T., Zhang, Y., Zhang, C., Luo, J. and Kong, L., 
(2017), Downregulation of TIGAR sensitizes the antitumor effect of physapubenolide through increasing intracellular ROS levels to trigger apoptosis and autophagosome formation in human breast carcinoma cells. Biochemical Pharmacology, 143, 90-106. https://doi.org/10.1016/ j.bcp.2017.07.018

Maryati and Sutrisna, E.M. (2001). Petroleum Ether Fraction of Physalis angulata L inhibited proliferation and induced apoptosis on HeLa Cell Line. Biota, 16(1).

Meiyanto, E., Supardjan, Da'i, M. and Agustina, D. (2006). Antiproliferative Effect of Pentagamavunon0 on Breast Cancer Cell Line T47D. Jurnal Kedokteran Yarsi, 14.

Nakamura, Y. (2004). Isolation of p53-target Genes and Their Functional Analysis. Cancer Science, 95(1), $7-11$. https://doi.org/10.1111/j.13497006.2004.tb03163.x

Mhaidat, N.M., Mohammed, B. and Thorne, R.F. (2014). 5-Fluorouracil-induced apoptosis in colorectal cancer cells is caspase-9-dependent and mediated by activation of protein kinase C- $\delta$, Oncology Letters, 8 (2), 699-704. https://doi.org/10.3892/ol.2014.2211

Qiu, L., Zhao, F., Jiang, Z.H., Chen, L.X., Zhao, Q., Liu, H.X., Yao, X.S. and Qiu, F. (2008). Steroids and flavonoids from Physalis alkekengi var. franchetii and their inhibitory effects on nitric oxide production. Journal of Natural Products, 71(4), 642646. https://doi.org/10.1021/np700713r

Sun, C.-P., Qiu, C.-Y., Zhao, F., Kang, N., Chen, L.-X. and Qiu, F. (2017). Physalins V-IX 16,24-cyclo13,14-seco with anolides from Physalis angulate and their antiproliferative and anti-inflamatory, Scientific Reports, 7(1), 4057. https://doi.org/10.1038/s41598017-03849-9

Sun, C.-P., Qiu, C.-Y., Yuan, T., Nie, X.-F., Sun, H.-X., Zhang, Q., Li, H.-X., Ding, L.-Q., Zhao, F., Chen, L. -X. and Qiu, F. (2016). Antiproliferative and antiinflammatory withanolides from Physalis angulata. Journal of Natural Products, 79(6), 1586-1597. https://doi.org/10.1021/acs.jnatprod.6b00094

Sun, L., Liu, J., Liu, P., Yu, Y., Ma, L. and Hu, L. (2011). Immunosuppression effect of withangulatin A from Physalis angulata via heme oxygenase 1dependent pathways. Process Biochemistry, 46(2), 482-488.

https://doi.org/10.1016/ j.procbio.2010.09.022

Wang, H.-Z., Zhang, Y., Xie, L.-P., Yu, X.-Y. and Zhang, R.-Q. (2002). Effects of Genistein and Daidzein on The Cell Growth. Cell Cycle and Differentiation of Human and Murine Melanoma
Cells. The Journal of Nutritional Biochemistry, 13 (7), 421-426. https://doi.org/10.1016/S0955-2863 (02)00184-5

Wyllie, A., Donahue, V., Fischer, B., Hill, D., Keesey, J. and Manzow, S. (2000). Cell Death Apoptosis and Necrosis. Germany: Rosche Diagnostic Corporation.

Xia, G., Li, Y., Sun, J., Wang, L., Tang, X., Lin, B., Kang, N., Huang, J., Chen, L. and Qiu, F. (2016). Withanolides from the stems and leaves of Physalis pubescens and their cytotoxic activity. Steroids, 115, 136-146.

https://doi.org/10.1016/

j.steroids.2016.09.002

Yang, Y.-K., Xie, S.-D., Xu, W.-X., Nian, Y., Liu, X.-L., Peng, X.-R., Ding, Z.-T. and Qiu, M.-H. (2016). Six new physalins from Physalis alkekengi var. franchetii and their cytotoxicity and antibacterial activity. Fitoterapia, 112, 144-152. https:// doi.org/10.1016/j.fitote.2016.05.010

Yin, F., Giuliano, A.E., Law, R.E. and Van Herle, A.J. (2001). Apigenin Inhibits Growth and Induces G2/M arrest by Modulating Cyclin-CDK regulators and ERK Maps kinase Activation in Breast Carcinoma Cells. Anticancer Research, 21(1A), 413-420.

Yu, W.F., Zhao, Y.L., Wang, K. and Dong, M.M. (2009). Inhibition of cell proliferation and arrest of cell cycle progression by blocking chloride channels in human laryngeal cancer cell line Hep-2. Neoplasma, 56(3), 224-229. https://doi.org/10.4149/ neo_2009_03_224

Zhang, Y., Chen, C., Zhang, Y.-L., Kong, L.-Y. and Luo, J-G. (2017). Target discovery of cytotoxic withanolides from Physalis angulata var. villosa via reactivity-based screening. Journal of Pharmaceutical and Biomedical Analysis, 151, 194199. https://doi.org/10.1016/j.jpba.2017.12.047 